\title{
The Knowledge of Pain Management among Nursing Students
}

\author{
Filiz Aslan' (D), Burcu Totur Dikmen² (D) \\ 'Department of First and Emergency Aid, Beykent University Vocational School, İstanbul, Turkey \\ ${ }^{2}$ Department of Surgical Nursing, Near East University Faculty of Nursing, Nicosia, Cyprus
}

ORCID iDs of the authors: F.A. 0000-0002-7843-0786; B.T.D. 0000-0002-422I-6II2.

Cite this article as: Aslan F, Dikmen BT. The Knowledge of Pain Management among Nursing Students. Cyprus J Med Sci. 2021; 6(3): 222-229.

\section{BACKGROUND/AIMS}

The aim of this study was to investigate the pain management knowledge of nursing students.

\section{MATERIAL and METHODS}

The sample of this study that was undertaken in descriptive design consisted of nursing department students of whom language of education was Turkish and English. To collect data, the study used a data collection form that was developed by the researchers between January and February 2018. In the evaluation of data, mean value, standard deviation, numbers, frequency analysis, KolmogorovSmirnov test, Levene test, Parametric hypothesis tests, t test, variance analysis, and Tukey test were used.

\section{RESULTS}

The sample consisted of 728 nursing students who voluntarily agreed to participate in the study. Of the participants, $66.76 \%$ were female, $32.14 \%$ were in the age-group of $22-23$, and $72.80 \%$ education language was Turkish. The study found a statistically significant difference between the scores of their general knowledge relating to pain, pharmacological, and nonpharmacological methods. The students need to receive the most knowledge in the field of the pharmacological management of pain.

\section{CONCLUSION}

The study results show, based on the overall score averages the students achieved from statements regarding pain management, that they have medium level of knowledge. The study suggests that training programs should be designed and sustained to address the students' knowledge gap in respect of pain management and enhance their educational level.

Keywords: Pain, pain management, nursing, students

\section{INTRODUCTION}

Pain is a distressing and subjective experience of sensual and emotional nature, which results from a certain area in the body and is related to real or potential tissue damage.,2 Pain negatively affects one's daily life activities, sleep cycle, working capacity, social life, and life quality., 3 . Pain level and control can vary depending on various aspects such as psychological state, fatigue, culture, and religious belief. ${ }^{5}$ Nowadays, pharmacological methods are generally used in controlling pain, which are preferred due to their easy implementation and rapid effects. ${ }^{6}$ Besides pharmacological methods, nonpharmacological methods such as massage, cold and heat applications, meditation, imagery, music therapy, aroma therapy, and acupuncture are also used to control pain. ${ }^{7,8}$

The aim of pain control is to minimize the discomfort of the patient, eliminate the pain, protect the suffering person from adverse effects, and enhance the life quality. In case where the pain is not effectively treated, it would persist and have both physical and psychological impacts on the affected individuals., 90

Pain can be taken under control through a multidisciplinary team work. "In their professional capacity as part of a healthcare team, nurses do play a pivotal role in relieving pain and improving the comfort of patients. ${ }^{12}$ The approach of nursing staff in pain management is of essential importance in eliminating pain or reducing it to a minimum level. ${ }^{13}$ In all the phases of pain beginning with diagnosis, nurses are one of the most important members in a healthcare team that make the greatest effort with respect to pain elimination. That nurses should properly assess pain in order to eliminate it as a matter of great priority in 
terms of an effective pain management. ${ }^{14,15}$ It is of great importance that nursing students have, as prospective nurses, due knowledge about pharmacological and nonpharmacological interventions used in pain management.

In the study investigating the student nurses' knowledge level, cultural awareness, and competence regarding pain management, Dirimeşe et al. ${ }^{16}$ report that they have medium level of knowledge in pain management, and their cultural awareness and competence in this respect are also at a medium level. In a study that examined the nursing students' attitudes to pain management, Fang et al. ${ }^{17}$ conclude that the students with a higher level of educational qualification have a higher level of knowledge of pain management compared with those with a lower educational level.

Plaisance and Logan ${ }^{18}$ demonstrated that nursing students had insufficient (64\%) information about pain management and suggested to improve education curriculum about pain management. Similarly, Al-Khaweldeh et al. ${ }^{19}$ revealed that nursing students had insufficient information about pain management and insufficient attitudes (34.1\%). Also, the other research which was conducted by Karaman et al. ${ }^{20}$ revealed that nursing students scored low in pain knowledge scores (40.64\%). It was thought that it might be beneficial to provide more education in baccalaureate about pain management to improve patients' life quality and to accelerate a healing process.

To educate and train student nurses into qualified nursing staff for the future, their knowledge level should be defined, and the deficiencies in this respect should be overcome. Defining the knowledge level of student nurses in pain management will provide a guiding framework for the planning regarding the required trainings. There was not found any study in Turkish Republic of Northern Cyprus (TRNC), which is similar to present study. This study aimed to investigate the pain management knowledge of nursing students of different nationalities in the nursing department of a university.

\section{Research Questions}

The study has addressed the following specific research questions:

I. What is the current knowledge level regarding pain management among baccalaureate nursing students in TRNC?

2. Are there any significant differences in knowledge regarding with pain management and personal information properties among baccalaureate nursing students?

\section{Main Points}

- It is vital to assess the students' knowledge levels regarding pain management that are attributable to their education processes.

- Male students' general knowledge regarding pain management and knowledge of non-pharmacological methods was significantly lower than that of female students.

- There is no significant differences between the scores of students based on the language in which they received their education (Turkish/English).

\section{MATERIAL and METHODS \\ Design and Sample}

The study was performed in descriptive design. The population of the study was composed of 1,095 students who studied in the nursing department attending lectures in Turkish and English in a University located in Nicosia in the TRNC. The sample, on the other hand, comprised 728 students who agreed to participate in the study on voluntary basis. Thus, the inclusion rate was $66.48 \%$.

The study was included all students of the nursing department in order to revealing the level of effect of pain management knowledge. Both Turkish and English department of nursing curriculum include 2 hours "pain and management" topics in the course of principles of nursing, 3 hours "surgical pain" topics in the course of surgical nursing, and I hour "birth pain" topics in the course of gynecology and obstetrics. Additionally, the course of Internal Medicine Nursing has included information on pain management in some topics.

\section{Instruments}

Personal information form and pain knowledge form were used, which were based on previous models and developed by the researchers to collect data. ${ }^{3,5,14,15,21-25}$

a. Personal information form: This form that includes nine questions was used to record the socio-demographic form regarding the participating students' information such as age, gender, ethnicity, the year of study, as well as information on trainings that students have received about pain management.

b. Pain knowledge form: This form was designed by the researchers based on a review of models available in the relevant literature. It is a form with 30 statements regarding pain management, which include general knowledge on pain and also the pain knowledge form consists of three subdimensions. The participants had to respond in options categorized as "true, false, and do not know." The first group of 10 statements in the form addresses general knowledge on pain, the second group of 10 statements in the form includes knowledge about pharmacological methods, and the third group of 10 statements in the form includes knowledge about nonpharmacological methods that are used in pain management.

For the evaluation of the responses, every statement indicated as "true" was scored with one (I), and statements indicated as "false" and "do not know" with zero (0). The level of general knowledge on pain management was evaluated on a scale varying between 0 and 30 scores; the total scores achieved showed whether the participant had higher or lower level of knowledge.

The form does not include cut point. Therefore, evaluation of the form was determined according to total score (30), which was accepted as (0-10) low, (10-20) middle, and (20-30) high.

\section{Validity of the Form}

The personal information form and pain knowledge form were designed in the first stage in a Likert-scale questionnaire with 50 questions with options "true, false, and do not know" as Turkish language. Then, the scales were translated to the 
English language by the translator and presented to four surgical nursing professors and one psychological professor specialized in the subject of the study reviewed and confirmed the content of the questionnaire, and a language specialist approved the clarity in terms of language. Based on the experts' opinions, the repeated, conflicting, and meaningless questions were excluded from the form. Then, the forms were amended in line with their views. The statements were categorized under three headings as general knowledge on pain, knowledge on pharmacological methods, and that on nonpharmacological methods, and as such the form included 30 statements in total. In the present study, the statement in the pain form was classified as true, false, and do not know which were included in the pain form. The form was then reviewed once more by the specialists, after which it was revised and adapted at some points and then finalized and adopted. Both forms were administered in a pilot questionnaire to examine their comprehensibility.

It was taken only expert opinions in order to apply the form. There was not to be done any analysis, because the form which was used in the study was not the scale.

\section{Pilot Study}

A pilot study was performed with 75 students, whom consist of 55 Turkish and 20 English nursing students for clarity on December 25-29, 2017. After the pilot study, no revision was necessary, and the nursing students who participated in the pilot study were included in the main sample.

\section{Procedure}

The data collection instruments were administered between January and February 2018. The aim of the study was explained to the students who had agreed to participate in the study, particularly with information on the principle of voluntary participation in the study. The questionnaire form was distributed in the classroom environment, where the participants completed the form in about 15-20 minutes.

\section{Data Analysis}

In statistical analysis of the forms, the Statistical Package for the Social Sciences (SPSS) version 24.0 (IBM SPSS Corp.; Armonk, NY, USA) was used. Besides, frequency analysis, Kolmogorov-Smirnov test, Levene test, parametric hypothesis test, $t$ test, variance analysis, and Tukey test were used to evalvate the study data.

\section{Ethical Consideration}

An ethical approval from the Ethical Review Board of the Near East University's Scientific Research Ethics Evaluation Board (approval date: December 21, 2017; approval number: YDU/ 2017 / 53-504), and an institutional permission from the administration of the Faculty of Nursing were obtained. In addition, a written informed consent was obtained from all participants.

\section{RESULTS}

Of the participating students, $66.76 \%$ were female, $32.14 \%$ in the age group of $22-23,72.80 \%$ education language was Turkish, and $27.34 \%$ continued their studies in the first year.

The study found, on the basis of participating students' knowledge on pain broken down by gender, a statistically significant difference between the scores of their knowledge on nonphar- macological methods and that on overall pain management ( $P$ $<$.05). The general knowledge of male students on pain, and also their knowledge on nonpharmacological methods and that on pain management were found to be significantly lower than the overall knowledge of female students. However, they had a similar level of knowledge on pharmacological methods. The general knowledge of pain of the students in the age group of 18-19, and also their knowledge on pharmacological and nonpharmacological methods were found to be significantly lower than the knowledge of the students in the age group of 22-23 and also than that of the students over 24 years of age. The study further demonstrated that the students in the first year of their studies had a lower level of overall knowledge on pain management than those in the third- and fourthyear students (Table I).

In the present study, reviewing the distribution of the responses to the statements regarding pharmacological and nonpharmacological methods used in pain management, we see that the statement "Pain has a negative effect on one's life quality $(T)^{\text {" }}$ has received the most responses indicated as true, and the statement "Visual comparison scale should be used in every patient (F)" was indicated as "false" by most of the students. As for the pharmacological methods used in pain management, it was the statement "Drugs should be used in effective dosages in pharmacological applications $(T)^{\prime}$ "that received the most "true" responses, and the statement "Short acting opioids should be used in patients with dull pain $(F)^{\prime \prime}$ was indicated as false by most of the students. As for the nonpharmacological methods, on the other hand, the statement that received the most "true" responses was the one "Nurses should eliminate the factors that increase pain $(T), "$ and the one which was indicated as false by most of the students was "Acupuncture treatment should only be used to treat headaches and pains at the abdominal area (F)" (Table 2).

The average score the participating students achieved in the statements concerning their general knowledge on pain was $6.71 \pm 2.01$, that in pharmacological methods $5.22 \pm 2.04$ and the one in nonpharmacological methods $6.01 \pm 2.63$, and their overall average score regarding their knowledge on pain was 7.95 \pm 5.53 . The lowest and the highest scores, which the students achieved, were 0 and 28 , respectively (Table 3 ).

The results show that $63.74 \%$ of the students had already received training on pain in general, of whom $74.57 \%$ expressed receiving this training at school, and $72.63 \%$ said that they were satisfied with the training they received.

What is more, results also demonstrated that the students who had training about pain were scored higher than students who had not any training about pain. There were not any statistically significant difference between place which students received training about pain and total pain of knowledge $(P>$ .05). Although students who were receive training about pain at school scored more higher than others, it was not statistically significant. Additionally, students, who were found sufficient in the education about pain, were found that statistically significant differences between knowledge about pain, knowledge about pharmacological methods in pain management, and total score of pain knowledge $(P<.05)$. Students who were found sufficient in the education about pain were scored more higher than students who were not found sufficient in the 


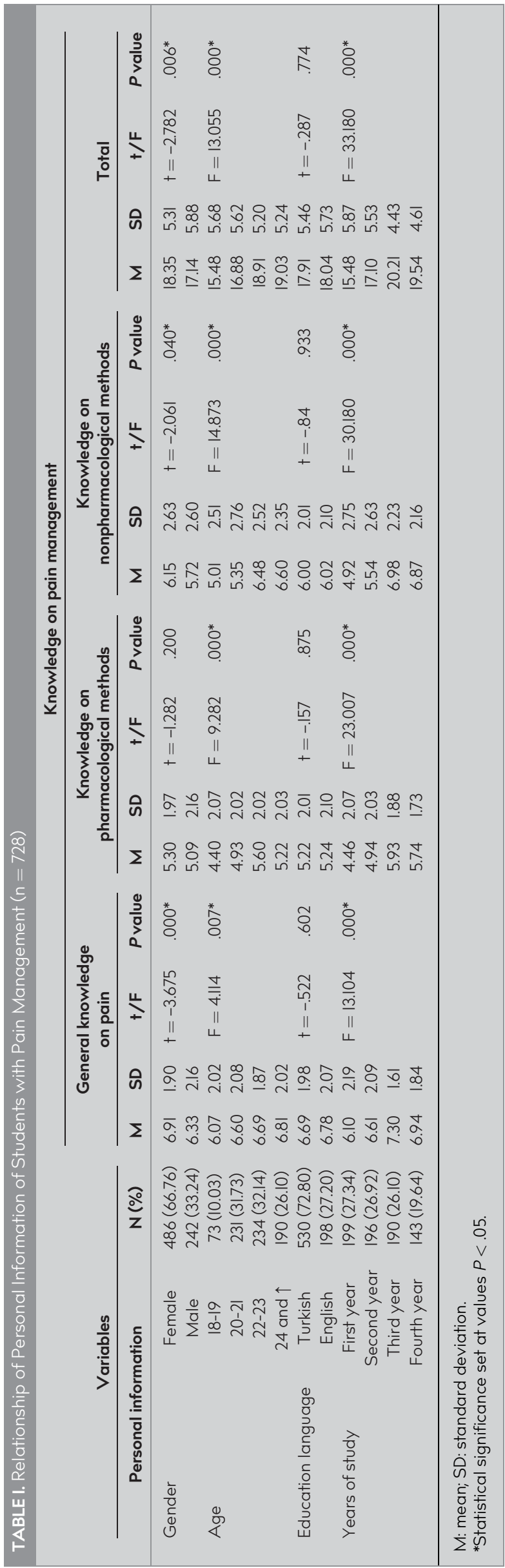

education about pain in knowledge about pain, knowledge about pharmacological methods in pain management, and total score of pain knowledge (Table 4).

The study found statistically significant, positive, and strong correlations between the students' knowledge scores regarding general knowledge on pain and that on pharmacological and nonpharmacological methods $(P<.05)$, meaning that higher scores in any of these knowledge fields referred to higher scores in others as well (Table 5).

\section{DISCUSSION}

The present study discusses the findings concerning the nursing students' knowledge on pain management in line with the findings observed in previous research.

In this study, there are $66.76 \%$ female and $33.24 \%$ male students. Results demonstrated that, male students' general knowledge of pain in pain management and knowledge of nonpharmacological methods were found to be significantly lower than female students.

The study did not demonstrate any significant differences between the students education language (Turkish/English) and also results demonstrated that their knowledge level was similar. Therefore, the results demonstrated that their department curriculum is similar.

Furthermore, results demonstrated that there is a significant difference between students' ages. Students who are between 18 and 19 scored lower in pain knowledge in totally compared to students who are between $22-23$ ages and 24 and above. This result might be because the most of students who are between 18 and 19 ages was studying at first class. Additionally, there was a difference between first, second, third, and fourth class of students in their general knowledge scores. It was not surprising situation that students who were studying at first class scored lower in knowledge level compared to students who were studying at third and fourth class.

Nowadays, despite significant developments in the field of education, it is generally observed that healthcare providers have poor knowledge and attitudes toward pain management. The literature has reported that medical and nursing students lack satisfactory knowledge of pain management, and that this lack has a negative effect on their knowledge and skills regarding pain management when working in healthcare settings after graduation. 3,22,23 It is therefore indispensable to investigate the students' knowledge levels of pain management in educational processes and overcome their lack of knowledge to enhance their knowledge and attitudes toward pain management in their professional life.

The accurate assessment of pain is the basis of effective pain management. Nurses who have important responsibilities in the evaluation of pain should have sufficient knowledge to evaluate their patients effectively. Students received the highest score from the subdimension, where general pain information was expressed. Therefore, this result demonstrated that students have moderate pain knowledge about pain.

The use of pharmacological management is common in pain control nowadays. This method provides to control pain with 
TABLE 2. The Responses of Students to the Items Relating to General Knowledge on Pain, Pharmacological and Nonpharmacological Methods on Pain Management $(n=728)$

\begin{tabular}{|c|c|c|c|c|c|c|}
\hline \multirow[b]{2}{*}{ Knowledge on pain management } & \multicolumn{2}{|c|}{ True } & \multicolumn{2}{|c|}{ False } & \multicolumn{2}{|c|}{ Do not know } \\
\hline & $\mathbf{N}$ & $\%$ & $\mathrm{~N}$ & $\%$ & $\mathrm{~N}$ & $\%$ \\
\hline \multicolumn{7}{|l|}{ General knowledge on pain } \\
\hline Pain is an indicator of an illness $(T)$ & 593 & 81.46 & 100 & 13.74 & 35 & 4.81 \\
\hline Pain should be accepted as the fifth vital sign $(T)$ & 396 & 54.40 & 125 & 17.17 & 207 & 28.43 \\
\hline Pain is a measurable indicator $(T)$ & 525 & 72.12 & $|4|$ & 19.37 & 62 & 8.52 \\
\hline Treatable pain is not a serious pain (F) & 263 & 36.13 & 385 & 52.88 & 80 & 10.99 \\
\hline Pain has a negative effect on one's life quality $(T)$ & 600 & 82.42 & 67 & 9.20 & 61 & 8.38 \\
\hline The first stage in pain management is pain assessment $(T)$ & 573 & 78.7I & 63 & 8.65 & 92 & 12.64 \\
\hline It is the person herself/himself who can correctly assess the pain $(T)$ & 580 & 79.67 & 85 & 11.68 & 63 & 8.65 \\
\hline During assessment, a person's self-report of pain has to be taken seriously $(T)$ & 544 & 74.73 & 97 & 13.32 & 87 & 11.95 \\
\hline $\begin{array}{l}\text { As pain provides clues in diagnosis and treatment of diseases. it should be accepted as } \\
\text { a vital sign }(T)\end{array}$ & 505 & 69.37 & 105 & 14.42 & 118 & 16.21 \\
\hline $\begin{array}{l}\text { Visual comparison scale should be used in every patient (F) } \\
\text { Knowledge on pharmacological methods }\end{array}$ & 376 & 51.65 & 187 & 25.69 & 165 & 22.66 \\
\hline Drugs should be used in effective dosages in pharmacological applications (T) & 585 & 80.36 & 75 & 10.30 & 68 & 9.34 \\
\hline In pain treatment only pharmacological methods should be used (F) & 228 & 31.32 & 379 & 52.06 & 121 & 16.62 \\
\hline Analgesics should only be administered through the oral way (F) & 199 & 27.34 & 334 & 45.88 & 195 & 26.79 \\
\hline Analgesics should be administered to the patients who have pain where necessary $(T)$ & 486 & 66.76 & 94 & 12.91 & 148 & 20.33 \\
\hline Short acting opioids should be used in patients with dull pain (F) & 375 & 51.51 & 136 & 18.68 & 217 & 29.81 \\
\hline $\begin{array}{l}\text { Patients should be informed about probable adverse effects of the analgesics used in } \\
\text { pain management }(T)\end{array}$ & 541 & 74.31 & 87 & 11.95 & 100 & 13.74 \\
\hline $\begin{array}{l}\text { Proper dosage should be administered to patients who have pain on a continual } \\
\text { manner }(T)\end{array}$ & 357 & 49.04 & 258 & 35.44 & 112 & 15.38 \\
\hline Pain treatment in surgical patients should start with strong pain-killers (F) & 350 & 48.08 & 155 & 21.29 & 223 & 30.63 \\
\hline The dosage should be tailored in line with the needs of patients $(T)$ & 501 & 68.82 & 113 & 15.52 & $\| 4$ & 15.66 \\
\hline $\begin{array}{l}\text { If PCA is to be applied, patients should be informed about the device, alarm system and } \\
\text { usage of buttons }(T)\end{array}$ & 529 & 72.66 & 78 & 10.71 & $|2|$ & 16.62 \\
\hline \multicolumn{7}{|l|}{ Knowledge on nonpharmacological methods } \\
\hline $\begin{array}{l}\text { Nurses can apply nonpharmacological methods proper for the characteristics and gen- } \\
\text { eral condition of a patient }(T)\end{array}$ & 519 & 71.29 & 93 & 12.77 & 116 & 15.93 \\
\hline Nurses should do planning for the reasons that cause an increase in pain $(T)$ & 529 & 72.66 & $10 \mid$ & 13.87 & 98 & 13.46 \\
\hline Nurses should eliminate the factors that increase pain $(T)$ & 540 & 74.18 & 91 & 12.50 & 97 & 13.32 \\
\hline In case of pain the position should be frequently changed $(T)$ & 409 & 56.18 & 149 & 20.47 & 170 & 23.35 \\
\hline $\begin{array}{l}\text { In using music in pain management, it is important to choose the type of music the } \\
\text { patient treated likes and prefers }(T)\end{array}$ & 505 & 69.37 & 88 & 12.09 & 135 & 18.54 \\
\hline $\begin{array}{l}\text { Techniques like vibration, meditation, aromatherapy and acupuncture are nonpharma- } \\
\text { cological methods }(T)\end{array}$ & 437 & 60.03 & 96 & 13.19 & 195 & 26.79 \\
\hline Aromatherapy relieves pain by distracting the patient or reducing the pain sensation $(T)$ & 449 & 61.68 & 82 & 11.26 & 197 & 27.06 \\
\hline Therapeutic touches reduce the pain by relaxing the patient $(T)$ & 472 & 64.84 & 91 & 12.50 & 165 & 22.66 \\
\hline $\begin{array}{l}\text { Acupuncture treatment should only be used to treat headaches and pains in abdominal } \\
\text { area (F) }\end{array}$ & 315 & 43.27 & 145 & 19.92 & 268 & 36.81 \\
\hline $\begin{array}{l}\text { Vibration is a method that can be used in acute and chronic muscle spasm pains, phan- } \\
\text { tom pains and malign pains }(T)\end{array}$ & 368 & 50.55 & 80 & 10.99 & 280 & 38.46 \\
\hline
\end{tabular}

The number and percentage of correct answers are indicated in bold-type.

\begin{tabular}{|lccccc|}
\hline TABLE 3. Knowledge Scores of Students Relating to Pain Management $(n=728)$ & & SD & Min \\
\hline Knowledge on pain management (score range) & N & M & 6.71 & 2.01 & 0 \\
\hline General knowledge on pain (0-I0) & 728 & 728 & 2.04 & 0 \\
Knowledge on pharmacological methods (0-10) & 728 & 6.01 & 0 & 10 \\
Knowledge on nonpharmacological methods (0-10) & 728 & 17.95 & 5.53 & 10 \\
Total scores (0-30) & & & \\
\hline M: mean; SD: standard deviation. & & &
\end{tabular}

pills. Pills are preferred by most of the people, because they have quick effect and used easily. ${ }^{7}$ This study demonstrated that students had moderate knowledge level in pain management about pharmacological applies and lowest knowledge in pain management. Dirimeşe et al. ${ }^{16}$ revealed that nursing students preferred mostly pharmacological methods considering patients' complaints, but they had a low level of knowledge about pharmacological methods. Furthermore, previous 
TABLE 4. Relationship of Pain Training Information of Students with Pain Management $(n=728)$

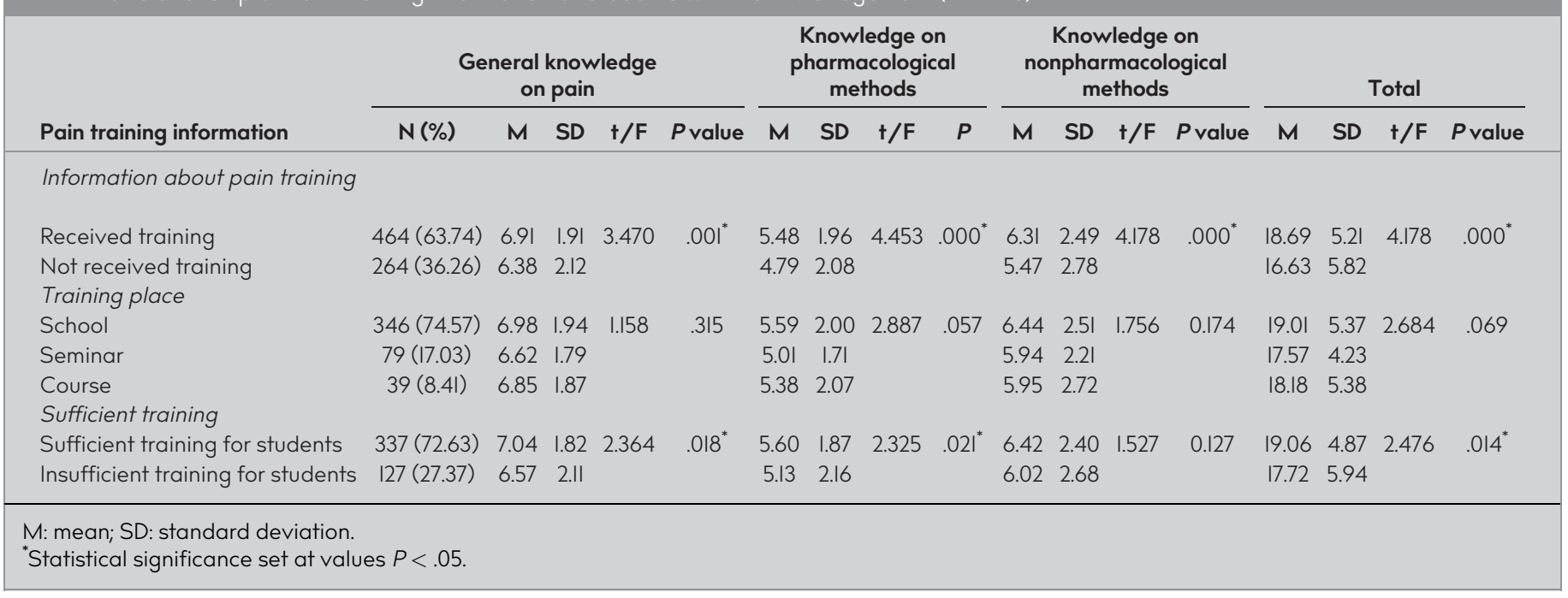

\begin{tabular}{|c|c|c|c|c|c|}
\hline Knowledge on pain management & & $\begin{array}{l}\text { General } \\
\text { knowledge } \\
\text { on pain }\end{array}$ & $\begin{array}{l}\text { Knowledge on } \\
\text { pharmacological } \\
\text { methods }\end{array}$ & $\begin{array}{l}\text { Knowledge on } \\
\text { nonpharmacological } \\
\text { methods }\end{array}$ & $\begin{array}{l}\text { Total } \\
\text { scores }\end{array}$ \\
\hline General knowledge on pain & $\begin{array}{l}r \\
P\end{array}$ & $\begin{array}{c}1 \\
.000^{*}\end{array}$ & & & \\
\hline Knowledge on pharmacological methods & $\begin{array}{l}r \\
P\end{array}$ & $\begin{array}{l}0.474 \\
.000^{*}\end{array}$ & 1 & & \\
\hline Total scores & $\begin{array}{l}r \\
P\end{array}$ & $\begin{array}{l}0.776 \\
.000^{*}\end{array}$ & $\begin{array}{l}0.818 \\
.000^{*}\end{array}$ & $\begin{array}{l}0.874 \\
.000^{*}\end{array}$ & । \\
\hline
\end{tabular}

research demonstrated that students were mostly insufficient in pharmacological methods in pain management. ${ }^{19}$ The present results are similar to previous research.

Nonpharmocological methods, which were using in pain management, can be provided to control the pain without medicine. Nonpharmacological methods could apply alone or by pharmacological methods. This method also has advantages such as low cost, applied easily, and does not have any side effects. ${ }^{6}$ In the present study, results demonstrated that there is a moderate level of knowledge about nonpharmacological methods and also there is not high level of differences compared to knowledge of pharmacological methods. Previous research demonstrated that there was a moderate level of knowledge about nonpharmacological methods $(n=244)^{7}$

Furthermore, the present study demonstrated that there was a moderate level of pain management knowledge and pharmacological and nonpharmacological knowledge level methods slightly higher.

The present study demonstrated that $63.74 \%$ students received training about pain and $36.26 \%$ students did not receive training about pain. Research demonstrated that students who received pain management training scored more higher in a total score of pain knowledge compared to students who did not receive training. Previous research, which was conducted by $\mathrm{Al}$-Khaweldeh et al., ${ }^{19}$ investigated the pain management training on students $(n=240)$, and the results demonstrated that students who received training scored more higher in the pain information level compared to students who did not receive any training. Constantly, Chiang et al. ${ }^{26}$ revealed that nursing students scored more higher in pain information and their skills after receiving the pain training. Results are similar to previous research.

This study also revealed the place that students receive pain training. $74.56 \%$ of students received training at school. The previous study that was conducted by Ozer et al. ${ }^{27}$ at nursing students demonstrated that $70.7 \%$ of students received training about pain so this result is similar to present study. Moreover, nursing students who received training about pain except school and scored a low level of pain knowledge might be because of the insufficient training, insufficient training program, or lack of training intervals.

Additionally, the study demonstrated that there was a statistically significant correlation between pain management scores, and these correlations are both positive and strong. Therefore, there is a positive correlation between knowledge about pain and general, pharmacological, and nonpharmacological pain. There were not any similar results in previous research. 
Previous research demonstrated that insufficient of practice about pain management and insufficient education about pain management might be the reason for lower level of pain knowledge. ${ }^{28,29}$

Furthermore, results demonstrated that nursing students who received pain management training were scored more higher in the knowledge level. In conclusion, it is thought that it might be beneficial to increase students' knowledge about pain management by putting to curriculum pain management topics.

In conclusion, based on the rate of the correct answers given by the students to the statements regarding pain management, the study found that they had a medium level of knowledge, which, however, increased in higher semesters. The study further showed that the students gave the most correct answers to the statements in the group general pain knowledge, and that their level of knowledge in this group was slightly higher than their knowledge on pharmacological and nonpharmacological techniques.

The present study also includes some limitations. First, most of students might have negative attitudes about survey form and these attitudes might affect their answers. Second, there were 1,095 students in total but some of them rejected to participate in the study. Therefore, the study consisted of 728 students. Third, the study was conducted only at a University, Department of Nursing Students so results were not generalized in TRNC.

Based on these results, the study recommends, besides ensuring the participation of students in teamwork in clinical and professional settings, overcoming students' deficiency in knowledge on pain management by including study courses of pain management in the curricula of nursing education and providing trainings with richer content of knowledge.

Ethics Committee Approval: Ethical committee approval was received from the Near East University's Scientific Research Ethics Evaluation Board (approval date: December 21, 2017; approval number: YDU/2017/ 53-504).

Informed Consent: Informed consent was obtained from the nursing students who participated in this study.

Peer-review: Externally peer-reviewed

Author Contributions: Conception - F.A., B.T.D.; Design - F.A., B.T.D.; Supervision - B.T.D.; Funding - F.A., B.T.D.; Materials - F.A., B.T.D.; Data Collection and/or Processing - F.A.; Analysis and/or Interpretation F.A., B.T.D.; Literature Search - F.A., B.T.D.; Writing - F.A., B.T.D.; Critical Reviews - B.T.D.

Acknowledgments: The authors would like to thank the nursing students studying in the Near East University Faculty of Nursing.

Conflict of Interest: The authors have no conflicts of interest to declare.

Financial Disclosure: The authors have declared that this study has received no financial support.

\section{REFERENCES}

I. Top FU, Usta T, Gücesan S. Sağlık bilimleri fakültesi öğrencilerinin belirlenmesi ve baş ağrılarının karakteristik özelliklerinin belirlen- mesi ve baş ağrısını geçirmek için uyguladıkları yöntemlerde kültürel inanışlarının değerlendirilmesi. Ağrı. 20।0;22(I):I3-20.

2. Gordon DB, Watt-Watson J, Hogans BB. Interprofessional pain education-with, from, and about competent, collaborative practice teams to transform pain care. Pain Rep. 2018;3(3):663.

3. Yılmaz F, Atay S. Hemşirelik öğrencilerinin klinik ağrı yönetimi. HU Hemşirelik Fakültesi Dergisi. 2014;|I(2):32-41.

4. Latchman J. Improving pain management at the nursing education level: Evaluating knowledge and attitudes. J Adv Pract Oncol. 2014;5(I):10-16.

5. Syrjala KL, Jensen MP, Mendoza ME, Yi JC, Fisher HM, Keefe FJ. Psychological and behavioral approaches to cancer. J Clin Oncol. 20|4;32(16):1703-17|I. [CrossRef]

6. Ozveren H. Ağrı kontrolünde farmakolojik olmayan yöntemler. HU Sağlık Bilimleri Fakültesi Hemşirelik Dergisi. 201l;18(I):83-92.

7. Ozveren $\mathrm{H}, \mathrm{Uccar} H$. Oğrenci hemşirelerin ağrı kontrolünde kullanılan farmakolojik olmayan yöntemlere ilişkin bilgileri. HU Sağlık Bilimleri Fakültesi Hemşirelik Dergisi. 2009;16(3):59-72.

8. Uzunçakmak T, Kılıç M. Pain experience of nursing students and the methods used to cope with pain. Ağrı. 2017;29(3):I17-121.

9. Faydalı S. Cerrahi hastalarda analjeziklerin kaliteli kullanımı. HU Sağlık Bilimleri Fakültesi Hemşirelik Dergisi. 20I0;17(2):83-91.

10. Kituyi WP, Imbaya KK, Wambani JO, Sisenda TM, Kuremu RT. Postoperative pain management: Clinicians' knowledge and practices on assessment and measurement at $\mathrm{MOI}$ teaching and referral hospital. East Cent Afr J Surg. 20ll;16(2):21-24.

II. Unver S, Ozkan ZK, Avcıbaşı IM, Dığın FB. Determining the postoperative pain management interventions of nursing students. HEAD. 2016;13(2):146-150. [CrossRef]

12. Midilli TS, Eşer I, Yücel Ş. Cerrahi kliniklerinde çalışan hemşirelerin ağrı yönetiminde nonfarmakolojik yöntemleri kullanma durumları ve etkileyen faktörler. ACU Sağlık Bil Derg. 2019;I0(I):60-66.

13. Yüceer S. Ameliyat sonrası ağrı yönetiminde hemşirelik yaklaşımları. Klinik ve Deneysel Araştırmalar Dergisi. 20ll;2(4):474478.

14. Malak A, Beji NK. Kronik pelvik ağrı ve hemşirelik yaklaşımı. Okmeydanı Tıp Dergisi. 2015;31(2):92-97.

15. Dikmen YD, Usta $Y Y$, İnce $Y$, Gel KT, Kaya MA. Hemşirelerin ağrı yönetimi ile ilgili bilgi, davranış ve klinik karar verme durumlarının belirlenmesi. Çağdaş Tıp Dergisi. 2012;2(3):I62-172.

16. Dirimeşe E, Ozdemir FK, Şahin ZA. Hemşirelik öğrencilerinin ağrı yönetimine ilişkin bilgi düzeyleri, kültürel farkındalıkları ve yeterlilikleri. GUSBD. 2016;5(3):I-6

17. Fang $L, X \cup Y$, Lin $D$, Jin J, Yan M. Attitude and intention regarding pain management among Chinese nursing student: A crosssectional questionnaire survey. Pain Manag Nurs. 2017;18(4):250259. [CrossRef]

18. Plaisance L, Logan C. Nursing students' knowledge and attitudes regarding pain. Pain Manag Nurs. 2006;7(4):167-175. [CrossRef]

19. Al-Khaweldeh OA, Al-Hussami M, Daravad M. Knowledge and attitudes regarding pain management among Jordain nursing student. Nurse Educ Today. 2013;33(4):339-345. [CrossRef]

20. Karaman E, Doğru BV, Yıldırım Y. Knowledge and attitudes of nursing students about pain management. Agrı. 2019;3I(2):70-78.

21. Ozlü ZK, İnce S, Avşar G. Müzik terapinin kolesistektomi olan hastaların ağrıları üzerine etkisi. Anadolu Hemşirelik ve Sağıık Bilimleri Dergisi. 2016;19(2):I00-105.

22. Ay F, Alpar ŞE. Postoperatif ağrı ve hemşirelik uygulamaları. Ağrı. 20I0;22(I):2I-29

23. Yılmaz M, Ozüm U, Gürler H, Çiftçi ES. Sağlık alanında eğitim alan üniversite öğrencilerinin ağrı kavramına ilişkin bilgileri. HEMAR-G Dergisi. 20I0;12(2):17-27. 
24. Aygin D, Var G. Travmalı hastanın ağrı yönetimi ve hemşirelik yaklaşımları. Turkiye Klinikleri J Med Sci. 2012;2(2):61-70.

25. Alakan YŞ, Unal E. Yoğun bakım hemşireliğinde ağrı değerlendirmesi ve ağrı yönetimi. HU Sağlık Bilimleri Fakültesi Dergisi. 2017;4(2):12-29. [CrossRef]

26. Chiang LC, Chen HJ, Huang L. Student nurses' knowledge, attitudes, and self-efficacy of children's pain management: Evaluation of an education program in Taiwan. J Pain Symp Manag. 2006;32(I):82-89. [CrossRef]
27. Ozer S, Akyürek B, Başbakkal Z. Hemşirelerin ağrı ile ilgili, davranış ve klinik karar verme yeten eklerinin incelenmesi. Ağrı. 2006;18(4):36-43.

28. Al Qadire M, Al Khalaileh M. Jordanian nurses knowledge and attitude regarding pain management. Pain Manag Nurs. 20|4;|15(I):220-228. [CrossRef]

29. Twycross A, Roderique L. Review of pain content in three-year preregistration pediatric nursing courses in the United Kingdom. Pain Manag Nurs. 20I3;14(4):247-258. [CrossRef] 